\title{
The expression of GST isoenzymes and p53 in non-small cell lung cancer
}

\author{
Serpil Ōguztüzūn', Mehtap Aydın², Funda Demiraḡ², Ülkü Yazıcı, \\ Müzeyyen Özhavzali ${ }^{4}$, Murat Kılıçể, Mesude İşcan ${ }^{5}$
}

\author{
${ }^{1}$ Department of Biology, Kirikkale University, 71451 Yahşihan-Kirikkale, Turkey \\ ${ }^{2}$ Department of Pathology, The Sanitarium Education and Research Hospital, Ankara, Turkey, \\ ${ }^{3}$ Department of Chest Surgery, The Sanitarium Education and Research Hospital, Ankara, Turkey, \\ ${ }^{4}$ Department of Mathematics, Kirikkale University, 71451 Yahşihan-Kirikkale, Turkey, \\ ${ }^{5}$ Department of Biology, Middle East Technical University, 06531 Ankara, Turkey.
}

\begin{abstract}
This study investigated the immunohistochemical staining characteristics of glutathione-S-transferase alpha, pi, $\mathrm{mu}$, theta and p53 in non-small cell lung carcinoma and normal lung tissue from 50 patients. The relationships between expressions of the Glutathione-S-transferase isoenzymes and some clinicopathological features were also examined. Expression of glutathione-S-transferase pi, mu, alpha, theta and p53 was assessed by immunohistochemistry for primary lung carcinomas of 50 patients from the Sanitarium Education and Research Hospital, Ankara lung cancer collection. The relationships between expression of the glutathione-S-transferase isoenzymes, p53 in normal and tumor tissue by Student T test and the clinicopathological data were also examined by Spearman Rank tests. When the normal and tumor tissue of these cases were compared according to their staining intensity and percentage of positive staining, glutathione-S-transferase alpha, pi, $\mathrm{mu}$, theta expressions in tumor cells was significantly higher than normal cells $(p<0.05)$. There was no significant difference in the expression of p53 between normal and tumor cells ( $>0.05$ ). When the immunohistochemical results of glutathione-S-transferase isoenzymes and p53 were correlated with the clinical parameters, there were no significant associations between glutathione-S-transferases and p53 expressions and tumor stage, tumor grade and smoking status (p $>0.05$ ).
\end{abstract}

Keywords: lung cancer, glutathione-S-transferase, p53, immunohistochemistry

\section{Introduction}

Tobacco exposure is an established risk factor for several cancers including lung carcinoma [1]. The development of tobacco related malignancies appears to depend on the duration and intensity of exposure to the carcinogen [2] as well as genetic susceptibility [1,2]. The presence of genetic susceptibilities is confirmed by the higher incidence of cancer in first-degree relatives of patients with lung carcinoma [3] and the interracial differences in the susceptibility to the carcinogenic effects of tobacco [4]. Understanding the mechanisms of susceptibility will facilitate the prevention and early detection of lung carcinoma.

Correspondence: S. Oguztüzün, Department of Biology, Kirikkale University, 71450 Yahşihan-Kirikkale, Turkey; tel.: (+90535) 4642445, fax.:(+90318) 3572461, 3572923, e-mail: soguztuzun@yahoo.com
The carcinogen metabolizing enzymes are involved in the activation and deactivation of diverse chemical carcinogens. Inter-individual and inter-racial variations in the expression of these enzymes in target tissues may explain the differences in susceptibility observed in clinical and epidemiological studies [5].

Potent carcinogens like polycyclic aromatic hydrocarbons (PAHs), aromatic and heterocyclic amines present in the diet, occupational and environmental exposures induce tumors, following metabolic activation to reactive derivatives that form DNA adducts [6].

The PAHs activated by hydroxylation can be detoxified via glutathione conjugation by glutathione-Stransferases (GSTs), which are phase-II metabolizing isoenzymes. They facilitate clearance of endogenous hydrophobic compounds such as hormones, steroids, haem, bilirubin, and bile acids. Furthermore, they are essential for metabolism of environmental carcinogens, drugs and pesticides by catalyzing the conjuga- 
tion of reactive chemical intermediates to soluble glutathione conjugates. Seven classes of cytosolic GSTs are recognized in mammalian tissues: alpha (GSTA), mu (GSTM), pi (GSTP), omega (GSTO), sigma (GSTS), theta (GSTT), and zeta (GSTZ) [7].

It was demonstrated that the GST detoxification capacity is tissue dependent in rodents [8]. Apart from the liver enzymes, most of the GST enzymes were also found in extrahepatic tissues such as muscle, testis, lung, brain, heart, blood and upper areodigestive mucosa [9-11]. The fact that most of the xenobiotic enzymes are expressed in a tissue-specific manner leads to great differences in the activation and inactivation of xenobiotics in different tissues.

In lung carcinoma, polymorphic GST isoenzymes may play a role in tumorigenesis and resistance to chemotherapy [12]. The GSTP is the most widely distributed isoenzyme [13]. It is expressed as a major form in many organs, such as lung, esophagus, kidney, and placenta [14]. Furthermore, expression of GSTP is elevated in many tumors relative to their matched normal tissue [15]. GSTP has been shown to be an useful marker for differential diagnosis in histopathology and intrinsic sensitivity to anticancer drugs of lung cancer [16].

Carcinogens and their metabolites result in malignant transformation through mutations altering the function of critical proto-oncogenes or tumor suppressor genes. The expression rate of altered p53 tumor suppressor gene was relatively high in small cell lung cancer (SCLC) without any prognostic significance [17].

The aim of this study was to evaluate the effects of the expression of GSTA (A), mu (M4), pi (P) and theta (T1) enzymes and p53 in normal and neoplastic lung tissue from the same patient group on the development of non-small cell lung carcinoma (NSCLC) and discuss their role in conjunction with known lung cancer prognostic factors.

\section{Material and methods}

Patients. For immunohistochemical studies, tissues from 50 patients with NSCLC at the Sanatoryum Education and Research Hospital were used. For all patients, tumor stage, smoking status, tumor grade status were available. Operation material was examined macroscopically by a pathologist in each case and two tissue samples were taken: one from the tumor tissue and one from the macroscopically normal tissue peripheral to the tumor tissue.

Immunohistochemical staining. The tissues were fixed in $10 \%$ buffered formalin and embedded in paraffin blocks. Sections that were $4 \mu \mathrm{m}$ thick were cut, and one section was stained with $\mathrm{H}+\mathrm{E}$ to observe the tissue morphology and tumor grade. For immunohistochemistry, endogenous peroxidase activity was blocked by incubating the sections in $1 \%$ hydrogen peroxide $(\mathrm{v} / \mathrm{v})$ in methanol for 10 minutes at room temperature (RT). The sections were subsequently washed in distilled water for 5 minutes and antigen retrieval was performed for 3 minutes using $0.01 \mathrm{M}$ citrate buffer
(pH 6.0) in a domestic pressure cooker. The sections were transferred in $0.05 \mathrm{M}$ Tris- $\mathrm{HCl}(\mathrm{pH} 7.6)$ containing $0.15 \mathrm{M}$ sodium chloride (TBS). After washing in water, the sections were incubated at RT for 30 minutes with either normal swine serum (for anti-GSTA, GSTP and p53) (1:20) or normal goat serum (for anti-GSTT1 and GSTM4) (1:20) diluted in TBS to block nonspecific binding. The sections were then covered with the primary antibodies diluted 1:100 for anti-GSTA, GSTP and p53; 1:50 for anti-GSTM4 and 1:500 for anti-GSTT1 in TBS at $4^{\circ} \mathrm{C}$ overnight (Monoclonal antibody against GSTT1 was from Labas International Limited, Estonia. Polyclonal antibodies against GSTA, GSTM4, GSTP and p53 raised in rabbit were purchased from Lab Vision Thermo Scientific, USA.) After washing in TBS (15 minutes) sections were incubated at RT for 1 hour with secondary antibody (swine-anti-rabbit Ig-biotinylated for anti-GSTA, GSTP and p53 or goat-anti-rabbit Ig-biotinylated for anti-GSTT1 and GSTM4) at a dilution of 1:100. Then, it was followed by treatment with avidin-biotin peroxidase complex (Dakopatts, Denmark). Diaminobenzidine was used to visualize peroxidase activity in the tissues. Nuclei were lightly counterstained with hematoxyline and then the sections were dehydrated and mounted. Both positive and negative controls were included in each run. Positive controls consisted of sections of normal human liver for GSTA, GSTM4 and GSTT1 and normal human small intestine for GSTP. TBS was used in place of the primary antibody for negative controls.

Immunohistochemically stained sections were examined by light microscopy without knowing the clinical information of the patients and the distribution, localization and the characteristics of immunostaining were recorded. Brown colour in cytoplasm and/or nucleus of the epithelial cells was evaluated as positive staining. Scoring was performed by both observers without knowledge of patient data. Scoring differences between observers were resolved by consensus. For each GST antibody, one feature to describe the immunoreactions was recorded using a semi quantitative scale: the relative number of positive cancer cells $(0 \%(-),<10 \%(1+), 11 \%$ to $50 \%(2+)$, or $>50 \%(3+))$. For p53 staining, the relative number of positive cancer cells $(<10 \%$, to $>10 \%)$ and positive and negative tumor nuclear staining were evaluated.

Statistical analysis. For each isoenzyme, staining scores in invasive and normal epithelium were compared statistically. The relationships between expression of the GST isoenzymes and p53 in normal and tumor tissue were examined by student $\mathrm{T}$ test. Clinicopathological data (tumor stage, tumor grade, and smoking status) were also examined by Spearman Ranks tests for checking that the relationships were significant or not.

\section{Results}

Fifty examples of NSCLC and normal from the surrounding lung tissue were examined from 50 patients (Table 1-2).

GSTA expression was stronger in tumor epithelium than normal epithelium in lung cancers (Table 1, $\mathrm{p}<0.05$ ). The $58 \%$ of the negative GSTA expression was normal epithelium and $70 \%$ of tumors were considered to have GSTA expression (Table 1). Fig. 1 showed that strong nuclear and cytoplasmic staining with GSTA was observed in lung adenocarcinoma cells.

Similarly, GSTT1 and GSTM4 expressions were higher in tumor epithelium than normal epithelium in human lung cancer. There were statistically significant differences in GSTT1 and GSTM4 expressions 
Table 1. Relationship between expressions of GSTA, GSTP, GSTT1, GSTM4 and p53 by normal epithelium and tumor epithelium in NSCLC according to the relative number of positive cancer cells.

\begin{tabular}{|c|c|c|c|c|c|c|c|c|c|c|c|c|c|c|c|c|c|c|c|c|}
\hline \multirow{3}{*}{$\begin{array}{l}\text { The relative } \\
\text { number of } \\
\text { positive } \\
\text { cancer cells }\end{array}$} & \multicolumn{4}{|c|}{ GSTT1 } & \multicolumn{4}{|c|}{ GSTP } & \multicolumn{4}{|c|}{ GSTA } & \multicolumn{4}{|c|}{ GSTM4 } & \multicolumn{4}{|c|}{ P 53} \\
\hline & \multicolumn{2}{|c|}{$\begin{array}{c}\text { lumor } \\
\text { epithelium }\end{array}$} & \multicolumn{2}{|c|}{$\begin{array}{l}\text { Normal } \\
\text { epithelium }\end{array}$} & \multicolumn{2}{|c|}{$\begin{array}{l}\text { Tumor } \\
\text { epithelium }\end{array}$} & \multicolumn{2}{|c|}{$\begin{array}{l}\text { Normal } \\
\text { epithelium }\end{array}$} & \multicolumn{2}{|c|}{$\begin{array}{l}\text { Tumor } \\
\text { epithelium }\end{array}$} & \multicolumn{2}{|c|}{$\begin{array}{l}\text { Normal } \\
\text { epithelium }\end{array}$} & \multicolumn{2}{|c|}{$\begin{array}{c}\text { Tumor } \\
\text { epithelium }\end{array}$} & \multicolumn{2}{|c|}{$\begin{array}{l}\text { Normal } \\
\text { epithelium }\end{array}$} & \multicolumn{2}{|c|}{$\begin{array}{l}\text { Tumor } \\
\text { epithelium }\end{array}$} & \multicolumn{2}{|c|}{$\begin{array}{c}\text { Normal } \\
\text { epithelium }\end{array}$} \\
\hline & $\mathrm{n}$ & $\mathrm{n} \%$ & $\mathrm{n}$ & $\mathrm{n} \%$ & $\mathrm{n}$ & $\mathrm{n} \%$ & $\mathrm{n}$ & $n \%$ & $\mathrm{n}$ & $\% \mathrm{n}$ & $\mathrm{n}$ & $n \%$ & $\mathrm{n}$ & $\mathrm{n} \%$ & $\mathrm{n}$ & $\mathrm{n} \%$ & $\mathrm{n}$ & $\mathrm{n} \%$ & $\mathrm{n}$ & $\mathrm{n} \%$ \\
\hline $0 \%(-)$ & 5 & 11 & 20 & 57 & 2 & 4 & 8 & 21 & 13 & 30 & 15 & 58 & 4 & 10 & 14 & 54 & 26 & 53 & 33 & 67 \\
\hline $1-10 \%(1+)$ & 19 & 41 & 7 & 20 & 18 & 38 & 21 & 57 & 9 & 20 & 8 & 31 & 16 & 37 & 6 & 23 & 23 & 47 & 16 & 33 \\
\hline $11-50 \%(2+)$ & 19 & 41 & 7 & 20 & 21 & 45 & 7 & 19 & 19 & 43 & 2 & 7 & 16 & 37 & 4 & 15 & - & - & - & - \\
\hline$>50 \%(3+)$ & 3 & 7 & 1 & 3 & 6 & 13 & 1 & 3 & 3 & 7 & l & 4 & 7 & 16 & 2 & 8 & - & - & - & - \\
\hline Total & 46 & & 35 & & 47 & & 37 & & 44 & & 26 & & 43 & & 26 & & 49 & & 49 & \\
\hline Asym. Sig.(p) & \multicolumn{2}{|c|}{$0.000^{*}$} & \multicolumn{2}{|c|}{$0.000^{*}$} & \multicolumn{2}{|c|}{$0.000^{*}$} & \multicolumn{2}{|c|}{$0.000^{*}$} & \multicolumn{2}{|c|}{$0.001^{*}$} & \multicolumn{2}{|c|}{$0.001^{*}$} & \multicolumn{2}{|c|}{$0.000^{*}$} & \multicolumn{2}{|c|}{$0.000^{*}$} & \multicolumn{2}{|c|}{$0.052^{*}$} & \multicolumn{2}{|c|}{$0.052^{*}$} \\
\hline
\end{tabular}

Correlation is significant at the $\mathrm{p}<0.05$ level (2-tailed). Asym.Sig: (p)

Table 2. Relationship between GSTA, GSTP, GSTT1, GSTM4 and p53 expressions with clinical and pathologic characteristics in NSCLC.

\begin{tabular}{|c|c|c|c|c|c|c|c|c|c|c|c|c|c|c|c|c|c|c|c|c|c|c|c|c|c|}
\hline \multirow{2}{*}{\multicolumn{2}{|c|}{\begin{tabular}{|c|} 
Paticnts \\
Characteristic \\
\end{tabular}}} & & \multicolumn{5}{|c|}{ GST A } & \multicolumn{5}{|c|}{ GST P } & \multicolumn{5}{|c|}{ GSTT1 } & \multicolumn{5}{|c|}{ GSTM4 } & \multicolumn{3}{|c|}{$\mathrm{p} 53$} \\
\hline & & & $(-)$ & $1+$ & $2+$ & $3+$ & Total & $(-)$ & $1+$ & $2+$ & $3+$ & Total & $(-)$ & $1+$ & $2+$ & $3+$ & Total & $(-)$ & $1+$ & $2+$ & $3+$ & Total & $(-)$ & + & Total \\
\hline \multirow{4}{*}{ 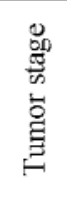 } & I & \multirow{4}{*}{$\mathrm{n}$} & 7 & 3 & 1 & 7 & 18 & 1 & 2 & 5 & 10 & 18 & 0 & 2 & 8 & 8 & 18 & 1 & 0 & 3 & 14 & 18 & 8 & 10 & 18 \\
\hline & II & & 1 & 2 & 4 & 12 & 19 & 0 & 1 & 2 & 16 & 19 & 1 & 0 & 6 & 12 & 19 & 0 & 1 & 1 & 17 & 19 & 7 & 12 & 19 \\
\hline & IIIB & & 4 & 0 & 5 & 4 & 13 & 0 & 3 & 2 & 8 & 13 & 0 & 0 & 6 & 7 & 13 & 2 & 1 & 0 & 10 & 13 & 4 & 9 & 13 \\
\hline & TOTAL & & 12 & 5 & 10 & 23 & 50 & 1 & 6 & 9 & 34 & 50 & 1 & 2 & 20 & 27 & 50 & 3 & 2 & 4 & 41 & 50 & 19 & 31 & 50 \\
\hline & & \multicolumn{6}{|c|}{$\mathrm{p}=0.044$} & \multicolumn{5}{|c|}{$\mathrm{p}=0.354$} & \multicolumn{5}{|c|}{$\mathrm{p}=0.387$} & \multicolumn{5}{|c|}{$\mathrm{p}=0.285$} & \multicolumn{3}{|c|}{$\mathrm{p}=0.735$} \\
\hline \multirow{4}{*}{ 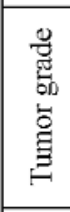 } & 1 & \multirow{4}{*}{$\mathrm{n}$} & 5 & 1 & 5 & 11 & 22 & 0 & 2 & 6 & 14 & 22 & 0 & 1 & 8 & 13 & 22 & 1 & 1 & 0 & 20 & 22 & 10 & 12 & 22 \\
\hline & II & & 4 & 4 & 4 & 8 & 20 & 1 & 3 & 1 & 15 & 20 & 1 & 1 & 8 & 10 & 20 & 1 & 1 & 4 & 14 & 20 & 7 & 13 & 20 \\
\hline & III & & 3 & 0 & 1 & 4 & 8 & 0 & 1 & 2 & 5 & 8 & 0 & 0 & 4 & 4 & 8 & 1 & 0 & 0 & 7 & 8 & 2 & 6 & 8 \\
\hline & TOTAL & & 12 & 5 & 10 & 23 & 50 & 1 & 6 & 9 & 34 & 50 & 1 & 2 & 20 & 27 & 50 & 3 & 2 & 4 & 41 & 50 & 19 & 31 & 50 \\
\hline & & \multicolumn{6}{|c|}{$\mathrm{p}=0.573$} & \multicolumn{5}{|c|}{$\mathrm{p}=0.519$} & \multicolumn{5}{|c|}{$\mathrm{p}=0.885$} & \multicolumn{5}{|c|}{$\mathrm{p}=0.265$} & \multicolumn{3}{|c|}{$\mathrm{p}=0.557$} \\
\hline \multirow{4}{*}{ 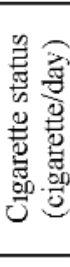 } & nonsmoker & \multirow{4}{*}{$\mathrm{n}$} & 4 & 2 & 2 & 1 & 9 & - & 5 & 4 & - & 9 & 2 & 3 & - & 4 & 9 & - & 2 & 1 & 6 & 9 & 2 & 7 & 9 \\
\hline & $\leq 30$ & & 5 & 4 & 2 & 11 & 22 & - & 4 & 13 & 3 & 20 & 3 & 3 & 6 & 10 & 22 & 1 & 3 & 2 & 16 & 22 & 12 & 10 & 22 \\
\hline & $>30$ & & 4 & 5 & 3 & 5 & 17 & 1 & 8 & 3 & 3 & 15 & - & 2 & 6 & 9 & 17 & 2 & 4 & 1 & 10 & 17 & 10 & 7 & 17 \\
\hline & TOTAL & & 13 & 11 & 7 & 17 & 48 & 1 & 17 & 20 & 6 & 44 & 5 & 8 & 12 & 23 & 48 & 3 & 9 & 4 & 32 & 48 & 24 & 24 & 48 \\
\hline & & \multicolumn{6}{|c|}{$\mathrm{p}=0.459$} & \multicolumn{5}{|c|}{$\mathrm{p}=0.096$} & \multicolumn{5}{|c|}{$\mathrm{p}=0.223$} & \multicolumn{5}{|c|}{$\mathrm{p}=0.861$} & \multicolumn{3}{|c|}{$\mathrm{p}=0.175$} \\
\hline
\end{tabular}

Correlation is significant at the $\mathrm{p}<0.05$ level (2-tailed). Asym.Sig: (p)

between normal and tumor epithelium $(\mathrm{p}<0.05)$ (Table 1). The $29 \%$ of the negative GSTM4 expression was normal epithelium, but $66 \%$ of tumors were considered to have strong GSTM4 expression (Fig. 2). Similarly, $57 \%$ of the negative GSTT1 expression was normal epithelium, but $41 \%$ of tumors were considered to have moderate GSTT1 expression (Table 1).

$45 \%$ of the moderate GSTP expression were tumor epithelium (Fig. 3) and 57\% of the normal were considered to have weak GSTP expression $(p<0.05)$. Thus, the stronger GSTP was observed in tumor epithelium than normal epithelium in human lung cancers. The $67 \%$ of the negative p53 expression was normal epithelium, and $47 \%$ of the tumor was considered to have positive $\mathrm{p} 53$ expression ( $>00.05$ ) (Fig. 4).

Histologic grade of the tumors was determined on $\mathrm{H}+\mathrm{E}$ stained slides. The 22 cases were grade I, 20 cases were grade II, and 8 cases were grade III invasive NSCLCs. Nineteen patients were in stage 1, 18 in stage 2 , and 13 in stage 3 .

When the clinical and pathologic characteristic of the lung cancers with the levels of GSTA, GSTP, 


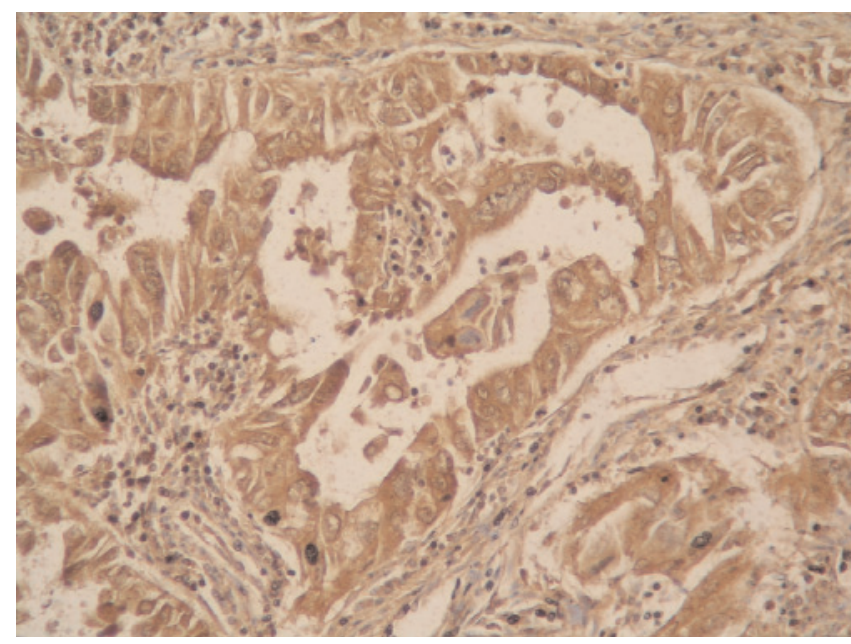

Fig. 1. This case of adenocarcinoma had strong nuclear and cytoplasmic staining with GSTA in more than $90 \%$ of the tumor (GSTA, original magnification $\times 400$ ).

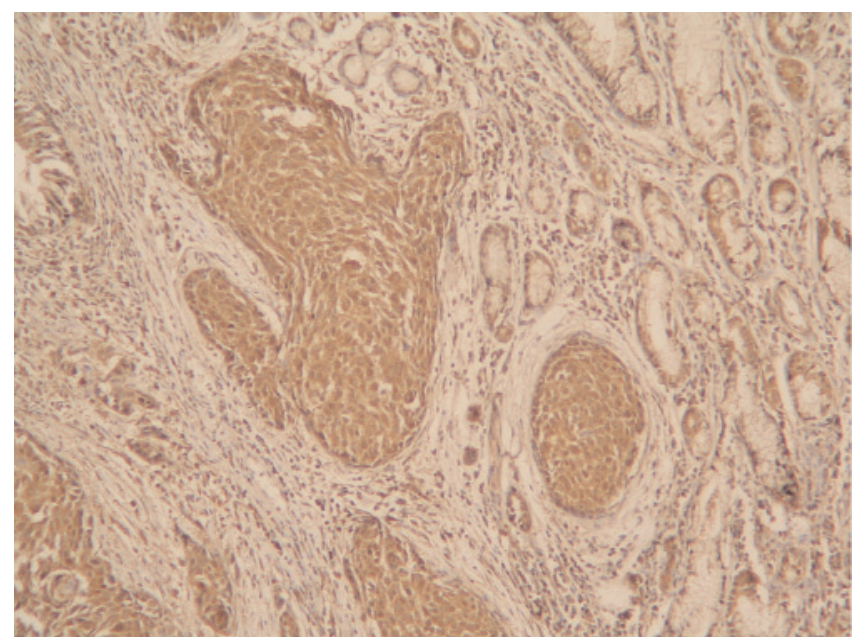

Fig. 2. A case of squamous cell lung carcinoma had moderate nuclear and cytoplasmic staining with GSTM4 in more than $90 \%$ of the tumor cells (GSTM4, original magnification $\times 100$ ).

GSTM4, GSTT1 and p53 expressions were correlated separately, there were no significant associations between tumor stage, smoking status and tumor grade and GSTs and p53 expressions in tumor tissue $(\mathrm{p}>0.05)$ (Table 2).

\section{Discussion}

Lung carcinoma remains a worldwide public health issue of immense proportions. In 2004, carcinomas of the lung and bronchus are expected to continue to account for the highest proportion of cancer deaths in the United States $(160,440$ deaths or $28.5 \%)$, more than the estimated total number of deaths due to carcinomas of the breast, prostate, colon and rectum combined [18]. Approximately $80 \%$ of lung carcinomas will have non-small cell carcinoma histology [19].

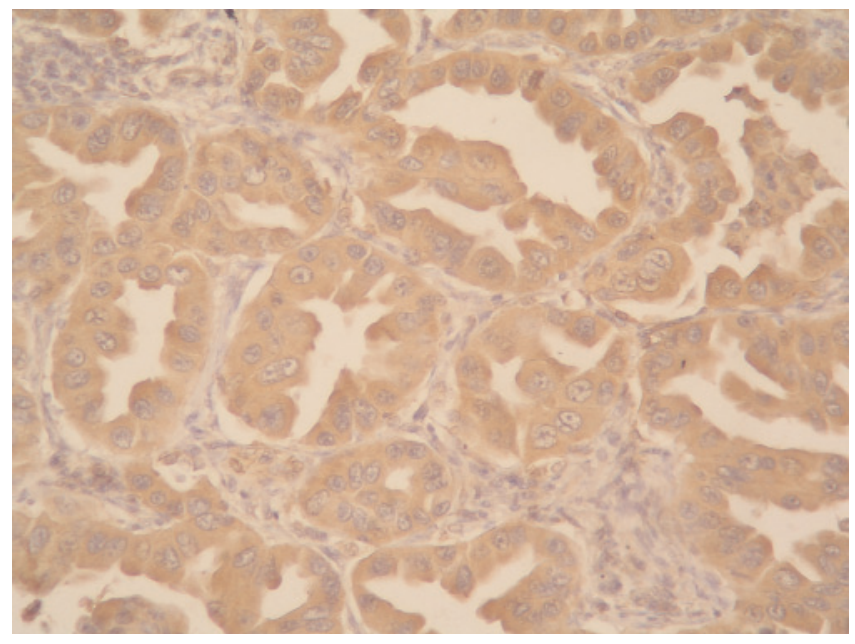

Fig. 3. An adenocarcinoma cells show moderate nuclear and cytoplasmic staining for GSTP. (GSTP, original magnification $\times 400$ )

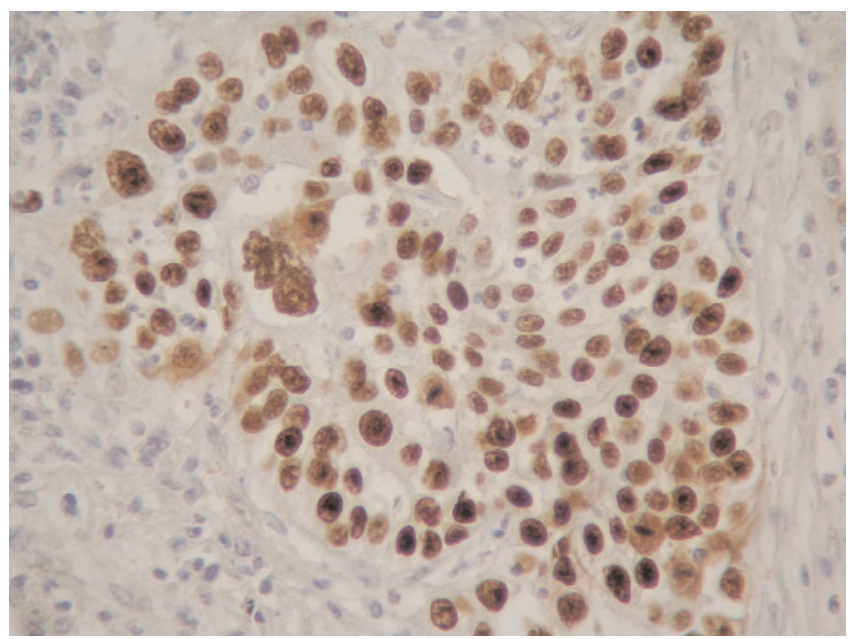

Fig. 4. This case of squamous cell lung carcinoma cells had strong nuclear staining in more than $80 \%$ of the tumor. (p53, original magnification $\times 400$ )

Smoking tobacco has been implicated as the main causative factor in development of lung cancer, and only about $1 \%$ of lung cancer occurs in nonsmokers.

Polycyclic aromatic hydrocarbons, aromatic amines, and nitroso compounds are among the carcinogens that have been identified in tobacco smoke [20]. The cytochrome P450 (CYP) enzymes oxidize these compounds yielding reactive epoxide intermediates, which can covalently bind and alter DNA structure [21]. GST enzymes catalyze glutathione conjugation of these intermediates, thereby decreasing their DNA damaging effects [22]. Variations in the expression of CYPs and GST could potentially explain the observed difference in vulnerability to the carcinogenic effects of tobacco. Previous studies have demonstrated the expression of CYPs and GST in normal squamous epithelium of the lung [23]. CYP and GST 
expression varies in different tissues [24,15]. Tissue metabolism of carcinogens by these locally expressed enzymes may be a more important determinant of carcinogenesis than metabolism in the more distant organs such as the liver. Several studies assessed the risk of lung cancer in relation to GST genotypes [2527]. However, inter-individual variations in the expression and activity of GST are dependent on genotypic as well as post-transcriptional factors, which may be tissue specific [28-30]. Therefore, the most direct method to evaluate the effects of GST on the carcinogenic effects of tobacco is to evaluate enzyme expression in the tissue of interest.

To our knowledge, this study represents the first comprehensive description of the four classes of GSTs in normal and tumor human lung. In this study, we observed stronger staining intensity for GSTP, GSTA, GSTM4 and GSTT1 in tumor epithelial cells when compared with normal cells $(\mathrm{P}<0.05)$. However, there was no difference in staining intensity for $\mathrm{p} 53$ between tumor epithelium and normal epithelium cells (Table $1, p>0.05$ ). Cancer cells reveal multiple genetic alterations resulting in morphological and functional differences from the normal cells. Tumor cells may change some of their functions (e.g. expression of some proteins) in the malignant transformation process. It can be speculated that higher level of GST expression in the tumor cells can be a result of this transformation. The current immunohistochemical investigation revealed appreciable expression of GSTP in $96 \%$ of NSCLC (Table 1). This value was slightly same or higher those reported earlier for carcinomas of the uterine cervix (96\%) [31] and colorectum (88\%) [32]. In a more extended study, Saydam and coworkers [33] and Hida and coworkers [34] reported significantly higher GST enzyme activity levels and plasma GSTP values in human lung cancers as compared with control tissues.

Arai and coworkers [35] using immunohistochemistry, detected GSTP in $56.2 \%$ of non-small cell lung cancer. Nie and coworkers [16] assessed GSTs isoenzymes composition by immunohistochemical technique. They found that the total positive rates of GSTP and GSTM4 in 89 cases of non-SCLC were $75.3 \%$ and $9.7 \%$ respectively. Among them squamous cell carcinoma were stained positively for GSTP in $93.5 \%$, and GSTM4 in $6.5 \%$, while adenocarcinoma were in $69.7 \%$, and $6.1 \%$ respectively.

As p53 is the most commonly mutated gene in human cancer, including lung squamous cell carcinoma, it has attracted a great deal of interest as a prognostic factor, diagnostic tool and therapeutic target [17]. Recent studies using immunohistochemical staining following antigen retrieval investigated the expression of p53 in 45 patients with non-small cell lung carcinomas and found that $40 \%$ of the tumors demon- strated positive of p53. However, p53 positive was not predictive as a prognostic factor for clinical outcome [36]. We have also used immunohistochemical staining following antigen retrieval techniques to investigate the expression of p53 in lung squamous cell carcinomas and adenocarcinoma, and found that p53 was expressed in $47 \%$ of NSCLC, but no statistically significant difference between normal and tumor tissue for p53 expression was observed.

In this study, there were no correlation between GSTs and p53 expressions and known prognostic indicators. Allen and coworkers [37] have examined the relationship between GSTP overexpression and histological stage in squamous cell lung carcinomas. They have reported that nuclear staining with GSTP in greater than $10 \%$ of the cells was closely associated with decreased survival $(\mathrm{P}=0.02)$ in stage I and II squamous cell lung carcinomas $(\mathrm{n}=40)$.

We observed that there was a non-significant relationship between GSTs, p53 expressions and tumor grade, and that there was a non-significant relationship between GSTs, p53 expressions and tumor stage.

Environmental carcinogen besides cigarette could induce lung cancer. Our findings indicated a non-significant relationship between GSTs, p53 expressions and smoking status of lung cancer patients.

The number of lung cancer patients in this analysis can be considered small. Future studies with substantially larger numbers of lung cancer patients will be needed to examine prospectively for the possible relationship between GST expression and prognostic factors.

\section{References}

[1] Yuspa SH, Shields PG. Etiology of cancer: chemical factors. In: V. T. Devita, S. Hellman, and S. A. Rosenberg (eds), Cancer: Principles and practice of Oncology 1. Philadelphia: Lippincott Williams \& Wilkins, 1993. pp. 179-194.

[2] Vineis P, Pirastu R. Aromatic amines and cancer. Cancer Causes Control. 1997;8:346-355.

[3] Schneider J, Bernges U, Philipp M, Woitowitz HJ. GSTM1, GSTT1 and GSTP1 polymorphism and lung cancer risk in relation to tobacco smoking. Cancer Letter. 2004;208:1:6574.

[4] Schwartz AG, Swanson GM. Lung carcinoma in African Americans and whites. A population-based study in metropolitan Detroit, Michigan. Cancer. 1997;79:45-52.

[5] Harris CC. Interindividual variation among humans in carcinogen metabolism, DNA adduct formation and DNA repair. Carcinogenesis. 1989;10:1563-1566.

[ 6] Li D, Wang M. Dhingra K, Hitelman WN. Aromatic DNA adducts in adjacent tissues of breast cancer patients: Clues to breast cancer etiology. Cancer Res. 1996;56:287-293.

[ 7] Hayes JD, Flaagan JU, Jowsey IR. Glutathione transferases. Annu Rev Pharmacol Toxicol. 2005;45:51-88.

[ 8] Tu CP, Weiss MJ, Li NQ, Reddy CC. Tissue-specific expression of the rat GST. J.Biol Chem. 1983;258(8):4659-62

[ 9] Matthias C, Bockmuhl U, Jahnke V. GSTP1 polymorphism: effects on susceptibility to oral/pharyngeal and laryngeal carcinomas. Pharmacogenetics. 1998;8(1):1-6 
[10] Matthias C, Jahnke V, Hand P. Immunohistologic and molecular genetic studies of the effect of GST on the development of squamous epithelial carcinomas in the area of the headneck. Laryngorhinootologie. 1999;78:182-8.

[11] Cantlay AM, Smith CA, Wallace WA, Lamb YD. Heterogeneous expression and polymorphic genotype of glutathioneS-transferases in human lung. Thorax. 1994;49:1010-1014.

[12] Coles BF, Kadlubar FF. Detoxification of electrophilic compounds by glutathione $\mathrm{S}$-transferase catalysis: determinants of individual response to chemical carcinogens and chemotherapeutic drugs? Biofactors. 2003;17:115-130.

[13] Suzuki T, Coggan M, Shaw DC, and Board PG. Electrophoretic and immunological analysis of human GST isoenzymes. Ann.Hum.Genet. 1987;51:95-106.

[14] Moscow JA, Fairchild CR, Madden MJ, Ransom DT. Expression of anionic GST and p-glycoprotein genes in human tissues and tumors. Cancer Res. 1989;49:1422-1428.

[15] Shea TC, Kelley SI, Henner WD. Identification of an anionic form of GST present in many human tumors and tumor cell lines. Cancer Res. 1988;48:527-533.

[16] Nie KR, Li CH, Zhu YJ. Immunohistochemical investigation on the expression of glutathione-S-transferases (GSTS) in lung cancer. Zhonghua Jie $\mathrm{He} \mathrm{He} \mathrm{Hu} \mathrm{Xi} \quad \mathrm{Za}$ Zhi.1993;16:3:141-143.

[17] Paik KH, Park YH, Ryoo BY, Yang SH. Prognostic value of immunohistochemical staining of p53, bcl-2, and Ki-67 in small cell lung cancer. $J$ Korean Med Sci. 2006;21:35-39.

[18] Jemal A, Tiwari RC, Murray T Cancer statistics. CA Cancer J Clin. 2004;54:8-29.

[19] 19.Travis W, Travis LB, Devesa SS. Lung cancer incidence and survival by histologic type. Cancer. 1995;75(1 Suppl):191-202.

[20] Cosman M, de los Santos C, Fiala R. Solution conformation of the major adduct between the carcinogen (+)-antibenzo[a]pyrenediol epoxide and DNA. Proc Natl Acad Sci USA. 1992;89:1914-8.

[21] Gelboin HV. Benzo[alpha]pyrene metabolism, activation and carcinogenesis: role and regulation of mixed-function oxidases and related enzymes. Physiol Rev. 1980;60:1107-66.

[22] Ryberg D, Skaug V, Hewer A. Genotypes of GSTM1 and P1 and their significance for lung DNA adduct levels and cancer risk. Carcinogenesis. 1997;18:1285-9.

[23] Ng DP, Tan KW, Zhao B, Seow A. CYP1A1 polymorphisms and risk of lung cancer in non-smoking Chinese women: influence of environmental tobacco smoke exposure and GSTM1/T1 genetic variation. Cancer Causes Control.2005; 16(4):399-405

[24] Strange RC, Faulder CG, Davis BA. The human GSTs:studies on the tissues distribution and genetic variation of the GST1, GST2, and GST3 isoenzymes. Ann Hum Genet. 1984;48:11-20.
[25] Sobti RC, Kaur P, Kaur S. Combined effect of GSTM1, GSTT1 and GSTP1 polymorphisms on histological subtypes of lung cancer. Biomarkers. 2008;13:282-95.

[26] Cote ML, Kardia SL, Wenzlaff A. Combinations of glutathione S-transferase genotypes and risk of early-onset lung cancer in Caucasians and African Americans: a populationbased study. Carcinogenesis. 2005;26:1158.

[27] Sorensen M, Autrup H, Tjonneland A. Glutathione S-transferase T1 null-genotype is associated with an increased risk of lung cancer. Int. J. Cancer. 2004;110:219-24.

[28] Smart J, Daly AK. Variation in induced CYP1A1 levels: relationship to CYP1A1, Ah receptor and GSTM1 polymorphisms. Pharmacogenetics. 2000;10:11-24.

[29] Anttila S, Tuominen P, Hirnoven A. CYP1A1 levels in lung tissue of tobacco smokers and polymorphisms of CYP1A1 and aromatic hydrocarbon receptor. Pharmacogenetics. 2001;11:501-9.

[30] Wandel C, Witte JS, Hall JM, Stein CM, Wood AJ, Wilkinson GR. CYP3A activity in African American and European American men: population differences and functional effect of the CYP3A4*1B5'-promoter region polymorphism. Clin Pharmacol Ther. 2000;68:82-91.

[31] Kodate C, Fukushi A, Narita T, Kudo H, Soma Y, Sato K. Human placental form of GSTP as a new immunohistochemical marker for human colonic carcinoma. Gann. 1986;77:226-9.

[32] Shiratori Y, Soma Y, Maruyama H, Sato S, Atsushi T, Sato K. Immunohistochemical detection of the placental form of glutathione S-transferase in dysplastic and neoplastic human uterine cervix lesions. Cancer Research. 1987;47:6806-6809.

[33] Saydam N, Kirb A, Demir O, Hazan E. Determination of glutathione, glutathione reductase, glutathione peroxidase and glutathione S-transferase levels in human lung cancer tissues. Cancer Lett. 1997;119(1):13-19.

[34] Hida T, Kuwabara M, Ariyoshi Y. Serum glutathione-S-transferase pi level as a tumor marker for non-small cell lung cancer. Cancer. 1994;73:1377-82.

[35] Arai T, Yasuda Y, Takaya T. Immunohistochemical expression of glutathione S-transferase pi in untreated primary non-small cell lung cancer. Cancer Detect. Prev. 2000;24:252-7.

[36] Miyatake K, Gemba K, Ueoka H, Nishii K. Prognostic significance of mutant p53 protein, p-glycoprotein and glutathione S-transferase pi in patients with unresectable nonsmall cell lung cancer. Anticancer Res. 2003;23:2829-2836.

[37] Allen TC, Granville LA, Cagle P. Expression of glutathione S-transferase pi and glutathione synthase correlates with survival in early stage non-small cell carcinomas of the lung. Hum. Pathol. 2007;38(2):220-7.

Submitted: 14 October, 2009 Accepted after reviews: 14 December, 2009 